\title{
Particle size of biochar as co-composted fertilizer: Influence on growth performance of lettuce and concentration of bioavailable soil nutrients under salinity stress conditions
}

Arifa Malik ${ }^{1}$, Shamim Gul ${ }^{1,2}$, Muhammad Hanan Buriro ${ }^{3}$, Hidayatullah Kakar ${ }^{4}$, Tariq Ziad ${ }^{4}$

${ }^{1}$ Department of Botany, University of Balochistan, Quetta, Pakistan

${ }^{2}$ Department of Natural Resource Sciences, McGill University, Quebec, Canada

${ }^{3}$ Balochistan Agricultural Research and Development Center, Quetta, Pakistan

${ }^{4}$ Agricultural research Institute, Quetta, Balochistan, Pakistan

*Corresponding author:

Dr. Shamim Gul

Assistant Professor (TTS), Department of Botany, University of Balochistan

Department of Natural Resource Sciences, McGill University, Quebec, Canada

Email:shamim.gul@mail.mcgill.ca

\begin{abstract}
This pot-based study investigated the influence of co-composted wood-derived biochar on lettuce growth performance under salinity and drought stress conditions. Biochar of two particle sizes; $>$ $2 \mathrm{~mm}$ and $<1 \mathrm{~mm}$ were co-composted with the mixture (1:1 ratio of dry weight) of cow and poultry manures. Co-composted biochars were applied at 5\% and 7\% rates in soil. Control treatments included the amendment of mixture of biochar with manure in soil. Pots were subjected to slight drought (48-55\% water filled pore space (WFPS) of soil) and non-drought conditions (60\% WFPS) and under 0 and $1.3 \mathrm{dS} \mathrm{m}^{-1}$ salinity. Results revealed that plants growth performance was significantly better under treatments of co-composted biochar and no salt stress conditions, than when mixture of biochar and manure was applied to soil as non-composted fertilizer. Under no stress condition, small particle-sized co-composted biochar increased root biomass by $786.2 \%$ than the large particle-sized co-composted biochar at same application rate. As compared to large-sized co-composted biochar, small sized co-composted biochar at high application rates increased root biomass by $167-245 \%$ but not leaf biomass under both stress conditions. Small particle-sized cocomposted biochar amendment also increased the phosphorus use efficiency (PUE) of lettuce leaves than large particle-sized co-composted biochar under no stress condition. The amendment of small-sized co-composted biochar also increased significantly the concentration of Olsen phosphorus in soil than the amendment of large-particle-sized co-composted biochar. In conclusion, amendment of small particle-sized co-composted biochar has the potential of attenuating salinity and drought stress in lettuce and promoting $\mathrm{P}$ cycling in soil.
\end{abstract}

Keywords: Co-composted biochar, drought, NUE, PUE, salinity 


\section{Introduction}

Biochar is a porous pyrogenous biomass, generated from incomplete combustion of any biomass (e.g. wood, manure, bone, algae, crop stover, husk, nut shells) under oxygen-deficient conditions [1]. Drought and salinity are the major limiting factors in agricultural lands of semi-arid and arid regions. Amendment of biocarbon ameliorates these conditions by enhancing water holding capacity and reducing salt concentration in the soil solution [2]. Biochar is a porous medium, and therefore has high adsorption capacity for nutrients, salts and toxins $[3,4,5,6]$. When it is further crushed into small particles, its surface area further increases, which may also increase its adsorption capacity for nutrients, salts and toxins [7, 8, 9]. This factor in return results in the elevation of salt and toxicity stresses in plants, allowing them to grow well [10, 11].

The positive influence of biochar can be achieved or enhanced further by its co-amended in soil with organic and synthetic fertilizers $[5,12]$. When mixed with organic wastes especially compost, or inorganic fertilizers, biochar absorbs nutrients and acts as a slow-release fertilizer in soil [13]. Compost-based biochars are made by either their mixing with composted organic fertilizers or by their co-composting with organic wastes $[13,14]$. This nutrient-loaded biochar is frequently reported for having a positive influence on crop yield and soil quality [13, 14]. More than $60 \%$ of land area of Pakistan is arid to semi-arid while salinity and drought are main limiting factors in agriculture in these dry regions [15]. Empirical evidences suggest that amendment of biochar attenuates the negative effect of salinity and drought in plants [4]. The 5\% amendment of slowpyrolyzed corn-straw biochar in saline soil, significantly increased yield of Quinoa by $7.6 \%$ under drought condition than the control treatment [16]. In another study, conducted in Sakha Agricultural Research Station, Egypt in saline sodic soil at 50\% field capacity of soil moisture, in which following fertilizers were used; 1) slow-pyrolyzed biochar produced from rice husk and corn stalk (1:1 ratio) and 2) vermicompost produced from maize and rice straw residues while green wastes and cow manure were used as feeds for worms. As compared to control treatment, vermicompost increased yield of wheat by $18.6 \%$, amendment of biochar increased yield by $21.6 \%$; whereas, when biochar was mixed with vermicompost, it increased yield by $29.6 \%$ [17]. In Balochistan, production of manure in dairy, poultry, sheep and goat farms is higher than its consumption as organic fertilizer (personal observation). As a consequence, huge amount of this bioresource is wasted, which causes air and water pollution. If this bioresource is utilized for the production of co-composted biochar, it will not only help reduce pollution but will also enhance 
agricultural production in Balochistan. In Balochistan biochar is available in timber markets, which is generally made from the wood of Acacia nilotica L.

The objectives of this study are to assess the influence of co-composted wood-derived biochar as function of its particle size, on biomass production, nitrogen use efficiency (NUE), phosphorus use efficiency (PUE) and concentration of soil nutrients under salinity and drought conditions. Following hypotheses are tested in this study; 1) small particle sized co-composted biochar has more positive influence on plant growth performance than large-particle sized co-composted biochar under salinity and drought stress conditions, 2) amendment of co-composted biochar increase concentration of nutrients in soil.

\section{Materials and methods}

\subsection{Preparation of co-composted biochar}

The waste (broken pieces) of wood biochar was purchased from timber market Quetta city. The biochar was further crushed with mortar and subsequently passed through two mesh sizes; $>2 \mathrm{~mm}$ and $<2 \mathrm{~mm}>1 \mathrm{~mm}$. The source of farmyard manure was cow dung while the poultry manure was obtained from local poultry farms. These manures were air-dried and mixed at 1:1 ratio; thereafter, this organic fertilizer was further mixed with small and large particle-sized biochars separately at 1:1 ratio. Thereafter, the biochar-manure mixture was composted for three months in open-lid containers from June 2, 2019 to August 30, 2019 according to the method of Ravindran et al. [18]. Table 1. Nitrogen and phosphorus concentrations in organic fertilizers

\begin{tabular}{lcc}
\hline Organic Fertilizer & Nitrogen $\left(\mathrm{mg} \mathrm{g}^{-1}\right)$ & Phosphorus $\left(\mathrm{mg} \mathrm{g}^{-1}\right)$ \\
\hline Small particle-sized biochar mixed with manure & & 5.14 \\
(for control treatments) & 10.53 & 5.71 \\
Small particle sized co-composted biochar & 5.32 & 5.42 \\
Large particle-sized co-composted biochar & 13.22 & \\
\hline
\end{tabular}




\subsection{Experimental design and growth of plants}

The experiment was carried out in plastic pots. Soil was obtained from an agricultural field of vegetable crops (mainly tomato, green chili and egg plants). The soil was silt loam with 5\% clay and $57.5 \%$ silt. Before use, soil was air dried and passed through $2 \mathrm{~mm}$ mesh sieve to remove pebbles and other debris. The following four factors were considered into account for this study; drought, salinity, organic amendments (as large-sized and small-sized co-composted biochars) and the application rates of organic amendments. Two amendment rates of co-composted biochars were considered; $30 \mathrm{t} \mathrm{ha}^{-1}$ (5\% in soil) and $40 \mathrm{t} \mathrm{ha}^{-1}$ (7\% in soil).

For drought and salinity factors, plants of each biochar treatment were subjected to salinity level of $1.3 \mathrm{dS} \mathrm{m}^{-1}$ by mixing dry $\mathrm{NaCl}$ at $2 \mathrm{~g} \mathrm{~kg}^{-1}$ rate in soil [19]. The treatments were 3 control treatments in which, mixture of non-composted manure and small particle-sized biochar at 1:1 ratio were added in soil at 5\% amendment rate. Control 1 was the treatment in which no salinity and water stress was applied, control 2 had salinity stress; whereas, control 3 had both salinity and drought stress. The other treatments were $5 \%$ and $7 \%$ amendment of small and large particle-sized co-composted biochars and plants were subjected to no stress, salinity stress, drought stress or both stress conditions. Each treatment had three replications with the total of 57 experimental units (pots).

Before sowing of seeds of lettuce, soil was watered to saturation point with known amount of water in each pot. This was to provide a soft bed for seeds to germinate and establish Linn and Doran (1984). Seeds of lettuce were broad casted in each pot on November 16, 2019 in temperature and humidity non-regulated plastic tunnel. After establishment of seedlings, seedlings were thinned to 10 plants per pot. Due to humidity (because of low temperatures and winter rainfalls), water contents did not drop below $\sim 48-50 \%$ water filled pore space (WFPS). Therefore, soil water was maintained to two WFPS levels; 48-55\% WFPS for drought treatment and 60\% WFPS following protocol of Gul and Whalen [20]. Pots were weighed on bi-weekly bases and water was adjusted to the desired WFPS.

\subsection{Analysis of plant traits}

The aboveground plant biomass of each pot was harvested on February 18, 2020. Biomass was oven-dried at $40^{\circ} \mathrm{C}$ for 48 hours and dry biomass was calculated. The oven-dried plant tissues were ground to homogenous material followed by their analysis for total nitrogen and phosphorus as 
described in [21]. The NUE and PUE of plants as nutrient efficiency ratio of plants were calculated as formulated by Baligar et al. [22];

Nutrient efficiency ratio for $\mathrm{N}$ or $\mathrm{P}=\frac{\text { Aboveground plant biomass }}{N \text { or } P \text { in plant tissue }}$

\subsection{Removal of roots and chemical analysis of soil samples}

After harvest of plants the pots were teared from two opposite sides. Soil with roots was taken out carefully. Soil was slightly shaken to loose root-soil system. Roots were removed carefully, washed, oven-dried for 48 hours at $40^{\circ} \mathrm{C}$ and the biomass of roots was measured. The soil of pots was air-dried, inorganic nitrogen $(\mathrm{N})$ and soluble inorganic phosphorus $(\mathrm{P})$ were extracted by dissolving soil in $2 \mathrm{M} \mathrm{KCl}$ solution at 1:5 soil:solution (w:v) ratio [23]. The extracts were subjected to analysis of mineral nitrogen $(\mathrm{N})$ and Olsen phosphorus (P) according to Sims et al. [24] and D'Angelo et al. [25] respectively. The dry biomass of roots of all plants in a pot was assessed; whereas, for measurement of length of lateral roots, healthiest plant of a pot was considered.

\section{Results}

\subsection{Plant growth performance}

\subsubsection{Dry biomass of leaves}

Significant differences were found between various treatments. Biomass was higher under no salt stress at both WFPS as compared to plants subjected to salt stress at both WFPS (Figure 1; P $\leq$ 0.05). As compared to three control treatments; i.e. small-sized biochar mixture with manure under conditions of (1) salt and water stress 2) salt but no water stress and 3) no salt and no water stress, co-composted biochars of both particle sizes, under no salt stress increased leaf biomass at both application rates (Figure 1; $\mathrm{P} \leq 0.05$ ). Under no salt stress, small-sized co-composted biochar at both amendment rates significantly increased the leaf biomass of spinach as compared to largesized co-composted biochar (Figure 1; $\mathrm{P} \leq 0.05$ ). Under no salt- but slight water-stress condition (i.e. 45-50\% WFPS), small co-composted biochar at high amendment rate significantly increased the leaf biomass as compared to the co-composted large-sized biochar treatment at low application rate (Figure 1; $\mathrm{P} \leq 0.05$ ). Under salt- and water-stress conditions small-sized co-composted biochar at high amendment rate, significantly increased the leaf biomass as compared to large-sized cocomposted biochar applied at low amendment rate (Figure 1; $\mathrm{P} \leq 0.05$ ). 

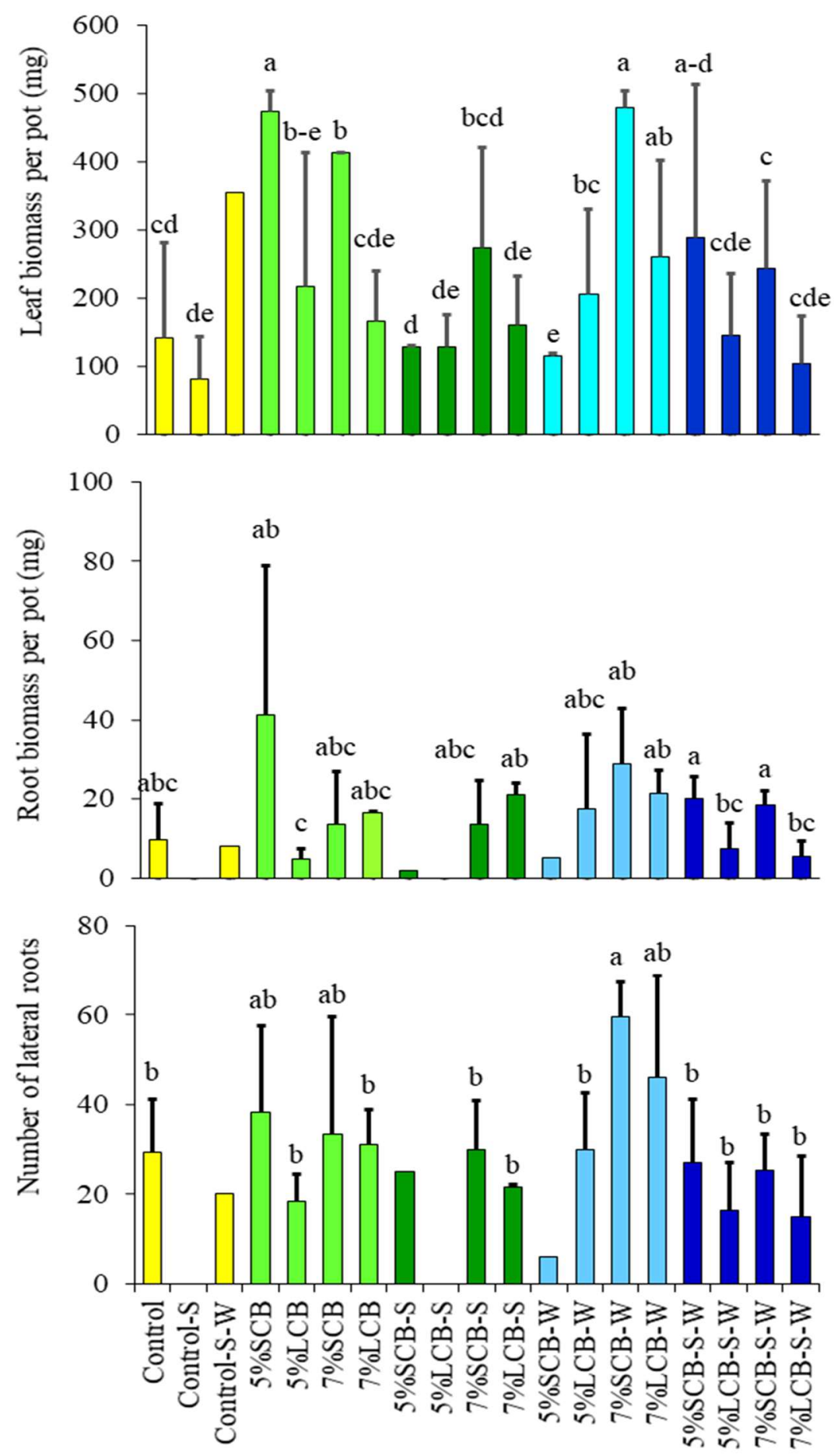

Figure 1. Mean $\pm \mathrm{SD}$ of aboveground plant biomass per pot (mg), root biomass per pot (mg) and total number of lateral roots. Control has amendment of biochar manure mixture at $5 \%$ amendment rate, S, salinity stress; W; water stress, SCB; small particle-sized co-composted biochar, LCB; large particle-sized co-composted biochar 5 and 7 represents biochar amendment rates. 


\subsubsection{Dry biomass of roots}

As was found for dry biomass of leaves, significant differences were found for dry biomass of roots (Figure 1). The positive effect of small-sized co-composted biochar on root biomass was evident for all factors tested, i.e. no stress, salt stress, water stress and salt + water stress conditions, as compared to large-sized co-composted biochar treatments (Figure 1 and 2; $\mathrm{P} \leq 0.05$ ).

\subsubsection{Length of main root system and number of lateral roots}

Small-sized co-composted biochar at 7\% application rate, under water stress condition, had a significant positive influence on length of main root and number of lateral roots than the plants that were grown under water + salt-stress conditions (Figure 1 and $2 ; \mathrm{P} \leq 0.05$ ). 
Large-sized biochar ( $<2 \mathrm{~mm}$ - > $1 \mathrm{~mm}$ )

Small-sized biochar $(<1 \mathrm{~mm})$

$30 \%$ WFPS, $1.3 \mathrm{ds}, 7 \%$ biochar amendment
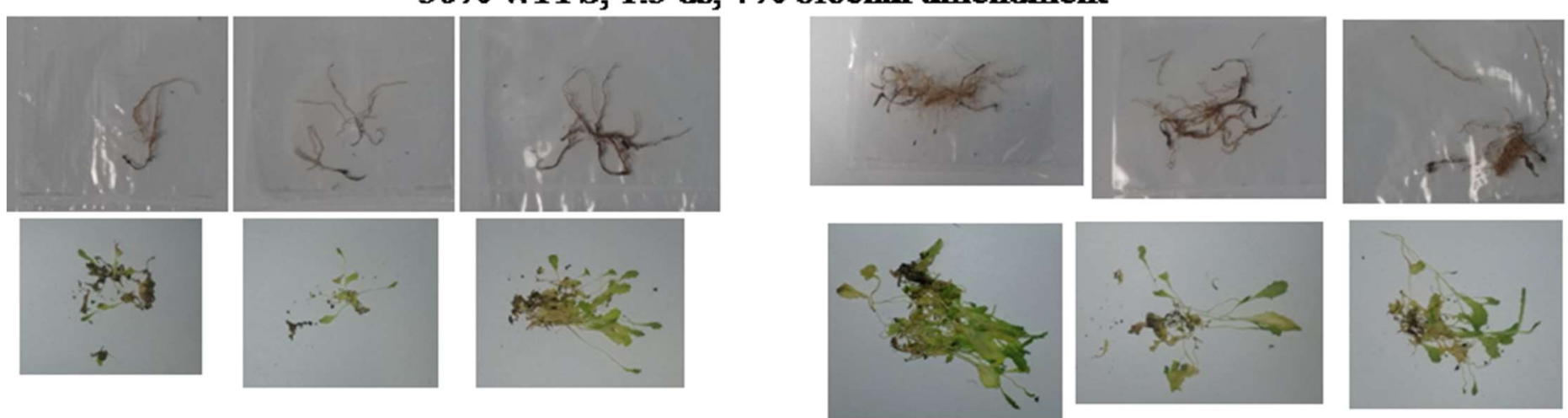

$30 \%$ WFPS, $1.3 \mathrm{ds}, 5 \%$ biochar amendment s
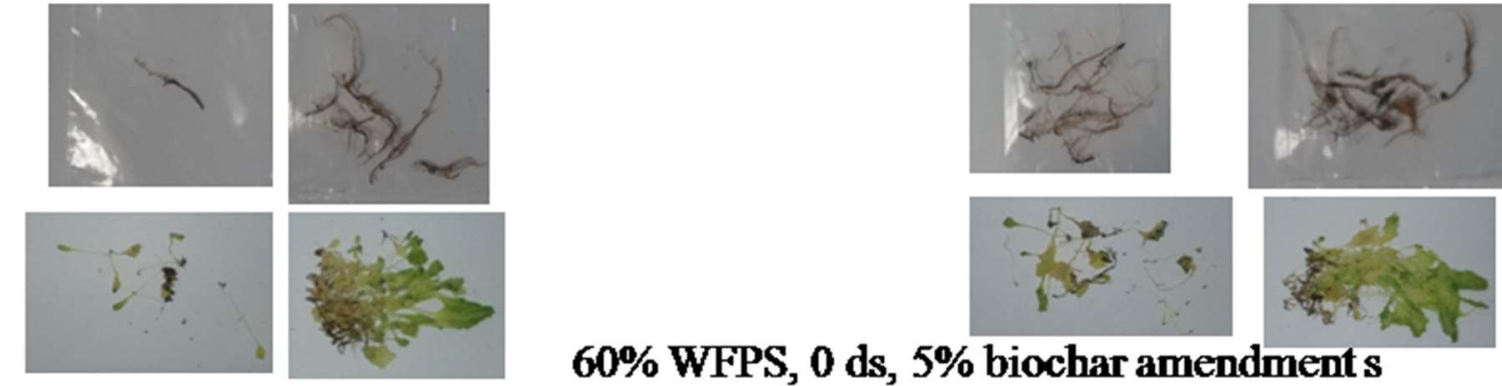

$60 \%$ WFPS, $0 \mathrm{ds}, 5 \%$ biochar amendment s
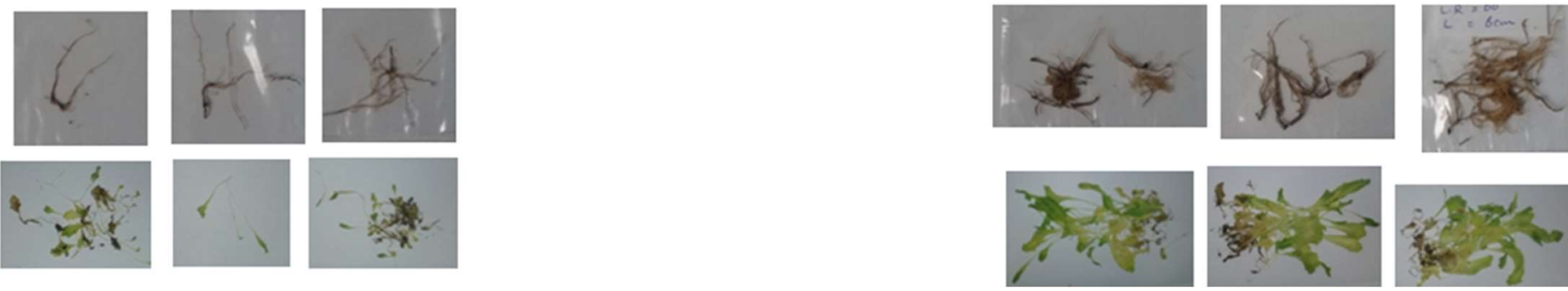

Figure 2: Pictures of roots (positioned above) and aboveground plant biomass (leaves; positioned below) of lettuce plants grown under various treatments 


\subsubsection{Concentration of $N, P N U E$ and PUE of lettuce leaves}

Significant differences were found between treatments regarding concentration of $\mathrm{N}$ in leaves (Table 1; $\mathrm{P} \leq 0.05$ ). Concentration of $\mathrm{N}$ in leaves was significantly higher in two treatments i.e. amendment of large-sized co-composted biochar at low application rate under water stress and no water stress conditions than co-composted biochars (both small- and large-sized), applied at high amendment rates under stress and no stress conditions (Table $1 ; \mathrm{P} \leq 0.05$ ).

The concentration of $\mathrm{P}$ in leaves were higher in the treatments of amendment of co-composted biochars at low amendment rates under salt stress condition as compared to most of other treatments (Table $1 ; \mathrm{P} \leq 0.05$ ).

The NUE of lettuce was significantly higher under treatments of small-sized co-composted biochar at 1) high application rate under salt stress condition and 2) at both application rates under nostress condition as compared to the other treatments (Table 1; $\mathrm{P} \leq 0.05$ ). As is observed for NUE, significant differences were also found for PUE of lettuce. The PUE was significantly higher under treatment of co-composted biochar of 1) large size at low amendment rate under only water-stress condition, 2) small- and large-sized co-composted biochars at high application rate under waterstress condition 3) small-sized co-composted biochars at both application rates under no stress conditions as compared to other treatments (Table $1 ; \mathrm{P} \leq 0.05$ ). 
Table 1. Mean \pm SD of nitrogen $\left(\mathrm{g} \mathrm{kg}^{-1}\right)$, phosphorus $\left(\mathrm{g} \mathrm{kg}^{-1}\right)$, nitrogen use efficiency (NUE) and phosphorus use efficiency (PUE) of lettuce plants under various treatments

\begin{tabular}{|c|c|c|c|c|}
\hline Treatment & $\mathrm{N}\left(\mathrm{g} \mathrm{kg}^{-1}\right)$ & $\mathrm{P}\left(\mathrm{g} \mathrm{kg}^{-1}\right)$ & NUE & PUE \\
\hline Control & $7.958 \pm 7.857^{\mathrm{abcd}}$ & $2.508 \pm 1.057^{\mathrm{c}}$ & $0.041 \pm 0.029^{\mathrm{bc}}$ & $0.117 \pm 0.117^{\mathrm{ab}}$ \\
\hline Control-S & $19.012 \pm 15.527^{\mathrm{abcd}}$ & $17.396 \pm 15.031^{\mathrm{bc}}$ & $0.022 \pm 0.037^{\mathrm{bcd}}$ & $0.005 \pm 0.0042^{\mathrm{d}}$ \\
\hline Control-S-W & 4.035829 & 0.282486 & & \\
\hline $5 \% \mathrm{SCB}$ & $4.409 \pm 2.807^{\mathrm{abcd}}$ & $2.561 \pm 0.782^{\mathrm{cd}}$ & $0.188 \pm 0.188^{\mathrm{ab}}$ & $0.199 \pm 0.055^{\mathrm{a}}$ \\
\hline $5 \% \mathrm{LCB}$ & $22.081 \pm 18.849^{\mathrm{ab}}$ & $7.265 \pm 7.544^{\mathrm{bcd}}$ & $0.022 \pm 0.022^{\mathrm{cd}}$ & $0.17232 \pm 0.265^{\mathrm{abcd}}$ \\
\hline $7 \% \mathrm{SCB}$ & $4.309 \pm 2.825 \mathrm{~b}^{\mathrm{c}}$ & $2.804 \pm 0.435^{\mathrm{c}}$ & $0.121 \pm 0.079^{\mathrm{ab}}$ & $0.148 \pm 0.022^{\mathrm{a}}$ \\
\hline 7\%LCB & $6.854 \pm 0.370^{\mathrm{bc}}$ & $2.977 \pm 2.147^{\mathrm{bcd}}$ & $0.027 \pm 0.01^{\mathrm{cd}}$ & $0.101 \pm 0.082^{b c}$ \\
\hline $5 \%$ SCB-S & $8.102 \pm 8.596^{\mathrm{abcd}}$ & $120.987 \pm 98.153^{\mathrm{a}}$ & $0.030 \pm 0.021^{\mathrm{cd}}$ & $0.001 \pm 0.000969^{\mathrm{d}}$ \\
\hline $5 \%$ LCB-S & $4.073 \pm 3.103^{\mathrm{bcd}}$ & $29.412 \pm 22.076^{\mathrm{b}}$ & $0.047 \pm 0.046^{\mathrm{bc}}$ & $0.006 \pm 0.004^{\mathrm{d}}$ \\
\hline $7 \%$ SCB-S & $2.793 \pm 0.660^{\mathrm{d}}$ & $1.872 \pm 2.272^{\mathrm{cd}}$ & $0.126 \pm 0.0034^{\mathrm{a}}$ & $1.136 \pm 1.707^{\mathrm{ab}}$ \\
\hline 7\%LCB-S & $5.055 \pm 0.774^{\mathrm{c}}$ & $2.809 \pm 1.851^{\mathrm{cd}}$ & $0.032 \pm 0.0089^{c}$ & $0.044 \pm 0.010^{\mathrm{c}}$ \\
\hline $5 \% \mathrm{SCB}-\mathrm{W}$ & $7.053 \pm 5.633^{\mathrm{bcd}}$ & $2.653 \pm 2.052 b^{\mathrm{cd}}$ & $0.042 \pm 0.052^{\mathrm{bcd}}$ & $0.062 \pm 0.037^{\mathrm{c}}$ \\
\hline $5 \% \mathrm{LCB}-\mathrm{W}$ & $16.835 \pm 4.677^{\mathrm{a}}$ & $1.101 \pm 0.743^{\mathrm{cd}}$ & $0.018 \pm 0.004^{\mathrm{d}}$ & $0.367 \pm 0.327^{\mathrm{a}}$ \\
\hline $7 \%$ SCB-W & $6.269 \pm 2.841^{\mathrm{bcd}}$ & $1.441 \pm 1.112^{\mathrm{cd}}$ & $0.093 \pm 0.053^{\mathrm{b}}$ & $1.215 \pm 1.706^{\mathrm{a}}$ \\
\hline 7\%LCB-W & $4.732 \pm 1.437^{\mathrm{c}}$ & $1.558 \pm 0.300^{\mathrm{d}}$ & $0.059 \pm 0.027^{\mathrm{b}}$ & $0.237 \pm 0.146^{\mathrm{a}}$ \\
\hline $5 \%$ SCB-S-W & $19.611 \pm 13.300^{\mathrm{ab}}$ & $1.744 \pm 1.517^{\mathrm{cd}}$ & $0.014 \pm 0.0019^{d}$ & $0.355 \pm 0.438^{\mathrm{abc}}$ \\
\hline $5 \%$ LCB-S-W & $14.526 \pm 9.169^{\mathrm{ab}}$ & $3.541 \pm 1.355^{\mathrm{bc}}$ & $0.014 \pm 0.016^{\mathrm{cd}}$ & $0.049 \pm 0.044^{\mathrm{b}}$ \\
\hline 7\%SCB-S-W & $8.934 \pm 9.082^{\mathrm{ab}}$ & $1.026 \pm 0.745^{\mathrm{d}}$ & $0.102 \pm 0.154^{\mathrm{abcd}}$ & $0.421 \pm 0.545^{\mathrm{abc}}$ \\
\hline 7\%LCB-S-W & $14.002 \pm 10.178^{\mathrm{abcd}}$ & $1.563 \pm 0.382^{\mathrm{d}}$ & $0.021 \pm 0.026^{\mathrm{cd}}$ & $0.086 \pm 0.059^{\mathrm{bc}}$ \\
\hline
\end{tabular}

Values within column, with different letters are significantly different at $\mathrm{P} \leq 0.05$. Control has amendment of biochar manure mixture at 5\% amendment rate, S, salinity stress; W; water stress, SCB; small particle-sized co-composted biochar, LCB; large particle-sized cocomposted biochar 5 and 7 represents biochar amendment rates. 


\subsubsection{Chemical analysis of soil samples}

In general, the concentration of $\mathrm{NO}_{3}{ }^{-} \mathrm{N}$ in soil was not significantly different between treatments except that it was significantly higher under treatments of 1) large-sized, co-composted biochar amendment at high application rate under salt + water stress and 2) small-sized co-composted biochar amendment at low application rate under water stress condition as compared to most of other treatments (Table 2; $\mathrm{P} \leq 0.05$ ). The amendment of large particle-sized co-composted biochar at high application rate, under no stress condition significantly reduced the concentration of $\mathrm{NO}_{3}{ }^{-}$ $\mathrm{N}$ than all other treatments (Table $2 ; \mathrm{P} \leq 0.05$ ).

The lowest concentration of Olsen $\mathrm{P}$ of soil was found under treatment of mixture of biochar with manure under no stress condition than most of other treatments (Table 2; $\mathrm{P} \leq 0.05$ ). The concentration of $\mathrm{P}$ was significantly higher in response to the amendment of small-sized cocomposted biochars amended at low and high application rates as compared to large-sized cocomposted biochar applied at same rates under no stress condition (Table 2; $\mathrm{P} \leq 0.05$ ). The amendment of small- and large-sized co-composted biochars at high application rates under both stress conditions and under only salt-stress condition had significantly higher concentration of $\mathrm{P}$ as compared to the amendment of large-sized co-composted biochar at low application rate under water stress condition (Table $2 ; \mathrm{P} \leq 0.05$ ). 


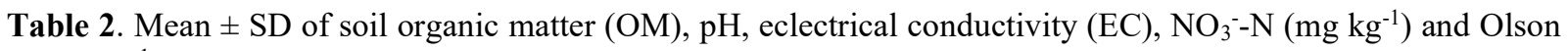
$\mathrm{P}\left(\mathrm{mg} \mathrm{kg}{ }^{-1}\right)$

\begin{tabular}{|c|c|c|c|c|c|}
\hline Treatment & $\mathrm{OM}$ & $\mathrm{pH}$ & $\mathrm{EC}$ & $\mathrm{NO}_{3}-\mathrm{N}$ & Olson P \\
\hline Control & $3.51 \pm 0.378^{\mathrm{ab}}$ & $7.9 \pm 0^{\mathrm{d}}$ & $2.263 \pm 0.296^{\mathrm{d}}$ & $114.871 \pm 103.915^{\mathrm{ab}}$ & $8.975 \pm 0.826^{\mathrm{d}}$ \\
\hline Control-S & $3.26 \pm 0.386^{\mathrm{ab}}$ & $8.043 \pm 0.068^{\mathrm{bcd}}$ & $4.337 \pm 0.608^{\mathrm{a}}$ & $230.769128 .265^{\mathrm{ab}}$ & $13.041 \pm 9.366^{\mathrm{abcd}}$ \\
\hline Control-S-W & $3.307 \pm 0.499^{\mathrm{ab}}$ & $8.013 \pm 0.118^{\mathrm{abcd}}$ & $5.277 \pm 1.705^{\mathrm{a}}$ & $172.307 \pm 58.704^{\mathrm{ab}}$ & $14.416 \pm 11.698^{\mathrm{abcd}}$ \\
\hline $5 \% \mathrm{SCB}$ & $3.363 \pm 0.622^{\mathrm{ab}}$ & $7.803 \pm 0.168^{\mathrm{d}}$ & $1.893 \pm 0.119^{\mathrm{e}}$ & $153.333 \pm 46.737^{\mathrm{b}}$ & $19.727 \pm 6.452^{\mathrm{ab}}$ \\
\hline $5 \% \mathrm{LCB}$ & $2.677 \pm 0.497^{\mathrm{ab}}$ & $7.997 \pm 0.080^{\mathrm{bc}}$ & $2.36 \pm 0.639^{\text {cde }}$ & $110 \pm 19.325^{\mathrm{bc}}$ & $12.658 \pm 1.448^{c}$ \\
\hline $7 \% \mathrm{SCB}$ & $3.463 \pm 0.642^{\mathrm{ab}}$ & $7.96 \pm 0.135^{\mathrm{abcd}}$ & $2.323 \pm 0.692^{\text {cde }}$ & $100.476 \pm 29.184^{\mathrm{bc}}$ & $25.220 \pm 4.736^{\mathrm{a}}$ \\
\hline $7 \% \mathrm{LCB}$ & $3.44 \pm 0.178^{\mathrm{a}}$ & $8.013 \pm 0.005^{\mathrm{c}}$ & $2.967 \pm 0.101^{\mathrm{cde}}$ & $89.524 \pm 7.047^{\mathrm{c}}$ & $17.670 \pm 5.507^{\mathrm{bc}}$ \\
\hline $5 \% \mathrm{SCB}-\mathrm{S}$ & $3.637 \pm 0.367^{\mathrm{a}}$ & $8.007 \pm 0.070^{\mathrm{bc}}$ & $4.46 \pm 0.588^{\mathrm{ab}}$ & $97.435 \pm 72.313^{\mathrm{b}}$ & $27.125 \pm 21.287^{\mathrm{abcd}}$ \\
\hline $5 \% \mathrm{LCB}-\mathrm{S}$ & $2.043 \pm 1.427^{\mathrm{b}}$ & $8.16 \pm 0.06^{\mathrm{a}}$ & $3.23 \pm 0.719^{\mathrm{bc}}$ & $112.307 \pm 88.792^{\mathrm{ab}}$ & $11.969 \pm 7.827^{\mathrm{bcd}}$ \\
\hline $7 \%$ SCB-S & $3.547 \pm 0.611^{\mathrm{ab}}$ & $7.933 \pm 0.117^{\mathrm{cd}}$ & $3.967 \pm 0.727^{\mathrm{ab}}$ & $183.663 \pm 130.258^{\mathrm{ab}}$ & $22.891 \pm 7.419^{\mathrm{ab}}$ \\
\hline $7 \% \mathrm{LCB}-\mathrm{S}$ & $3.22 \pm 0.375^{\mathrm{ab}}$ & $8.057 \pm 0.080^{\mathrm{abc}}$ & $4.177 \pm 1.292^{\mathrm{ab}}$ & $203.333 \pm 70.946^{\mathrm{ab}}$ & $22.650 \pm 17.489^{\mathrm{abcd}}$ \\
\hline $5 \%$ SCB-W & $3.143 \pm 0.402^{\mathrm{ab}}$ & $7.795 \pm 0.332^{\mathrm{bcd}}$ & $4.247 \pm 1.200^{\mathrm{ab}}$ & $389.873 \pm 286.35^{\mathrm{a}}$ & $16.827 \pm 10.728^{a b c}$ \\
\hline $5 \% \mathrm{LCB}-\mathrm{W}$ & $3.12 \pm 0.582^{\mathrm{ab}}$ & $7.953 \pm 0.180^{\mathrm{bcd}}$ & $3.387 \pm 0.698^{\mathrm{bc}}$ & $160.759 \pm 38.9^{\mathrm{b}}$ & $11.666 \pm 3.45^{\mathrm{cd}}$ \\
\hline $7 \%$ SCB-W & $3.21 \pm 0.137^{\mathrm{ab}}$ & $8.05 \pm 0.036^{\mathrm{bc}}$ & $3.087 \pm 0.627^{\mathrm{cd}}$ & $203.946 \pm 81.432^{\mathrm{b}}$ & $14.075 \pm 3.438^{b c}$ \\
\hline $7 \% \mathrm{LCB}-\mathrm{W}$ & $3.367 \pm 0.146^{\mathrm{a}}$ & $8.047 \pm 0.015^{b}$ & $4.263 \pm 0.551^{b}$ & $202.051 \pm 101.052^{\mathrm{ab}}$ & $15 \pm 1.907^{\mathrm{bc}}$ \\
\hline $5 \%$ SCB-S-W & $3.05 \pm 0.07^{\mathrm{ab}}$ & $8.033 \pm 0.109^{\mathrm{abcd}}$ & $5.357 \pm 1.16^{\mathrm{a}}$ & $132.911 \pm 23.203^{b}$ & $10.860 \pm 3.449^{\mathrm{bcd}}$ \\
\hline $5 \% \mathrm{LCB}-\mathrm{S}-\mathrm{W}$ & $3.023 \pm 0.512^{\mathrm{ab}}$ & $8.167 \pm 0.028^{\mathrm{a}}$ & $5.133 \pm 1.49^{\mathrm{a}}$ & $168.776 \pm 31.11^{\mathrm{b}}$ & $14.150 \pm 6.908^{\mathrm{bcd}}$ \\
\hline $7 \%$ SCB-S-W & $3.203 \pm 0.615^{\mathrm{ab}}$ & $8 \pm 0.036^{b c d}$ & $4.52 \pm 0.88^{\mathrm{ab}}$ & $151.1 \pm 13.9^{\mathrm{b}}$ & $19.677 \pm 2.793^{\mathrm{ab}}$ \\
\hline 7\%LCB-S-W & $3.337 \pm 0.316^{\mathrm{ab}}$ & $8.16 \pm 0.075^{\mathrm{a}}$ & $5.43 \pm 0.49^{\mathrm{a}}$ & $316.8 \pm 144.2^{\mathrm{a}}$ & $13.827 \pm 2.831^{b c}$ \\
\hline
\end{tabular}

Within column values with different uppercase letters are significantly different at $\mathrm{P} \leq 0.05$. Control has amendment of biochar manure mixture at 5\% amendment rate, S, salinity stress; W; water stress, SCB; small particle-sized co-composted biochar, LCB; large particle-sized co-composted biochar 5 and 7 represents biochar amendment rates. 


\section{Discussion}

\subsection{Aboveground plant biomass}

The growth of plant leaves were higher in response to the amendment of small-sized co-composted biochar at both application rates and co-composted large-sized biochar at high application rate as compared to the control treatments. For instance, control treatment under salt stress condition had 412 - 489\% lower leaf biomass than the plants under treatment of small and large-sized cocomposted biochar under no salt stress condition. Similarly, under no stress conditions, plants that were grown under treatment of mixture of biochar with manure (control treatment), had 85 - 240\% lower leaf biomass than the plants under treatments of co-composted biochars. These results indicate that biochar as co-composted fertilizer had a significant profound positive influence on lettuce growth than when the biochar was applied in soil as a mixture with manure. Our results are in agreement with other published empirical evidences that co-composted biochar or compostbiochar mixture has more profound positive influence on crop growth than when the biochar is mixed with non-composted organic wastes in soil [26, 27, 7, 28]. Zainul et al., [26] reported 23\% significant higher dry biomass (root + shoot) production of Phragmite skarka in response to the amendment of compost-biochar mixture than only biochar. Likewise Qayyum et al. [27] reported $27 \%$ increase in the grain yield of wheat in response to the amendment of co-composted biochar (garden peat biochar co-composted with farmyard manure at 1:1 w/w ratio) than when only compost of farmyard manure was amended at the same rate.

The difference between co-composted biochars under stress versus no stress condition was also significant. For instance, lettuce biomass under treatments of small-sized co-composted biochar at both application rates and large-sized co-composted biochar at high application rate, in no saltstress condition was higher by $61-73 \%$ than the plants under treatment of co-composted biochar in salt stress condition and by $41-78 \%$ higher than the plants under treatment of co-composted biochar in salt + water stress condition. The porous nature of biochar enable it to adsorb nutrients, salts and toxins from soil $[3,4,5,6]$. The surface area of biochar further increases when it is crushed in smaller particles; therefore, adsorption capacity of biochar also increases [7, 8,9]. This factor further improves capacity of biochar to adsorb more toxins and salts from soil, thus improves growth performance of crops by alleviating stress to plants [10, 11, 29]. This may be the reason that amendment of small particle-sized co-composted biochar in general had more positive 
influence on lettuce leaf biomass production under salinity and drought stress conditions than large particle-sized co-composted biochar amendment.

\subsection{Root biomass}

Under salt + water stress condition, root biomass was significantly higher by $167-245 \%$ in response to the amendment of small particle-sized co-composted biochar at both application rates than the plants that were grown in soil, which was amended with large particle-sized co-composted biochar. This finding indicates that under salinity and drought-stress conditions, small-sized cocomposted biochar had more positive influence on plant root growth as compared to large-sized co-composted biochar. Under no stress condition, small particle-sized co-composted biochar increased root biomass by $786 \%$ than the large particle-sized co-composted biochar at same application rate. In saline soil, positive influence of biochar on root biomass has been reported [30]. Slow pyrolyzed maize straw biochar amendment at 4\% w/w in saline soil in pot significantly increased root biomass by $\sim 26 \%$ as compared to the control treatment (saline soil without biochar amendment) [30].

\subsection{NUE and PUE of lettuce leaves}

As was observed for aboveground plant biomass and root biomass, obvious differences are found between small particle-sized versus large particle-sized co-composted biochar treatments. Under stress or non-stress conditions, NUE of lettuce was higher under treatments of small particle-sized co-composted biochars than large particle-sized co-composted biochars (Table 2). It indicates that small-particle-sized co-composted biochar alleviated the stress of water and salt for plants and therefore, improved their nitrogen use efficiency. The significant positive influence of cocomposted biochar on NUE of crops is frequently reported [31, 32, 33]. Luo et al. [32] reported a significant positive influence of co-composted biochar on growth and NUE of two halophytes i.e. Kosteletzkya virginica (seashore mallow) and Sesbania canabina (sesbania), which is also a medicinal plant [34]. However, influence of co-composted biochar as function of its particle size during its composting has not been reported. Nutrient-loaded biochar is the mixture of biochar or its co-composting with organic fertilizers e.g. compost, urine, manure etc. $[35,6,12]$. This nutrient-rich organic amendment acts as slow-release fertilizer besides improving soil properties [36]; therefore, it also improves crop growth performance [37].

More profound results are found for the PUE of plants, where under all conditions (e.g. water stress, salt stress, water and salt stress and no stress conditions), PUE of lettuce leaves was 
significantly higher in response to the amendment of small particle-sized co-composted biochar as compared to large particle-sized co-composted biochar. Our results are consistent with the findings of Manzoor et al. [9] who observed more profound positive response of pea plants for PUE than NUE to the amendment of biochar + cow manure mixture than control. Our results indicate that under drought and salinity stress, small-particle-sized co-composted biochar tend to improve the plant growth performance specifically when it is applied at high application rate.

\subsection{Soil properties}

The highest concentration of nitrate in soil was found under the treatment of co-composted biochar of large and small particle-sized at high and low application rates respectively, at both stress conditions as compared to the treatments which caused increased leaf biomass production than these treatments i.e. small particle-sized co-composted biochar amendment at both application rates under no stress condition and small particle-sized co-composted biochar amendment at high application rate under water stress condition. In general, concentration of nitrate was higher in soil, which yielded lower leaf biomass production as compared to the soil that yielded higher leaf biomass production. We attribute this effect to the high absorption of nitrate by plants which had high leaf biomass. Biochar is well-known for reducing mineral $\mathrm{N}$ loss through leaching and gaseous emissions as nitrous oxide and ammonia volatilization from soils including saline soils (literature review by Gul and Whalen, [5, 38, 39]. The low uptake of $\mathrm{N}$ by plants, possible nitrogen mineralization by microbes and possible low $\mathrm{N}$ losses might had resulted in high $\mathrm{N}$ concentration in these treatments.

Contrary to the results of nitrate, concentration of Olsen $\mathrm{P}$ had a positive relation with leaf biomass production. As compared to control treatment co-composted biochar treatments significantly increased the concentration of Olsen $\mathrm{P}$ of soil by 35 - 64\%. Interestingly, under no stress condition, small particle-sized co-composted biochar significantly increased concentration of Olsen $\mathrm{P}$ at both application rates as compared to large particle-sized co-composted biochar at both amendment rates. The positive influence of biochar or biochar-compost amendment in soil on biochemical cycling of $\mathrm{P}$ is frequently reported [5, 40,41]. Biochar-based organic fertilizers improve root growth and associated high secretions of organic acids in rhizosphere, which help mobilize phosphorus from its precipitated to bioavailable form [5]. The labile organic carbon from rice rhizosphere and decomposing litter in ultisol and oxisol paddy soils reduced Fe III to Fe II, which in return caused mobilization of phosphorus [42]. Further research is required to investigate the 
role of co-composted biochar on $\mathrm{P}$ cycling and its bio-availability via improving microbial processes (P mineralization and solubilisation) and physico-chemical processes of soil.

\section{Conclusion}

The lettuce plants responded differently to the amendment of co-composted biochar versus when biochar was mixed with cow manure in soil. The application of biochar as co-composted fertilizer, under no stress condition, had significantly positive influence on the growth performance of lettuce as compared to, when biochar was applied to soil as a non-composted fertilizer, which was made by mixing biochar with manure at 1:1 w:w ratio. A profound difference was also observed between large particle-sized versus small particle-sized co-composted biochar on growth performance of lettuce. Lettuce plants showed positive response to the amendment of small particle-sized cocomposted biochar at high application rate under both salinity and drought stress than large particle-sized co-composted biochar. Small-sized co-composted biochar amendment also increased PUE of plants under stress or no stress conditions than large particle-sized co-composted biochar. Moreover, small particle-sized co-composted biochar also increased the concentration of Olsen $\mathrm{P}$ in soil than large particle-sized co-composted biochar amendment in soil.

\section{Acknowledgement}

This research work is supported by National Research Program for Universities grant (grant \# 9664).

\section{Declarations}

\section{Ethics approval and consent to participate}

Authors declare no conflict of interest associated with this research. This research work is not submitted in another journal. Authors declare acknowledgment of all ethics associated with science and give consent to participate.

\section{Availability of data and material}

The raw data of all tested parameters associated with this work are provided as supplementary material

\section{Funding}

This research work is supported by National Research Program for Universities grant (grant \# 9664).

\section{Authors' contributions}


Miss Arifa Malik performed research and wrote manuscript, Shamim Gul and Abdul Hanan Buriro supervised and provided research facilities associated with this research work, Tariq Ziad provide assistance in laboratory analysis of soil and plant samples, Kanval Shaukat and Tariq Ismail contributed in data analysis and presentation of results.

\section{Supplementary Description}

The raw data of all tested parameters associated with this work are provided as supplementary material

Table: Leaf biomass (mg)

Table: Number of roots per pot, lateral roots number per plant, length of main root, weight of roots per pot

Table: N (mg g-1), P (mg g-1), NUE and PUE of lettuce leaves

Table: Soil electrical conductivity, $\mathrm{pH}$, organic matter $\left(\mathrm{g} \mathrm{kg}^{-1}\right)$, Olsen $\mathrm{P}\left(\mathrm{mg} \mathrm{kg}^{-1}\right)$, nitrate $\left(\mathrm{mg} \mathrm{kg}^{-}\right.$ $\left.{ }^{1}\right)$ of soil samples 
Large-sized biochar ( $<2 \mathrm{~mm}$ - > $1 \mathrm{~mm}$ )

Small-sized biochar $(<1 \mathrm{~mm})$

$30 \%$ WFPS, $1.3 \mathrm{ds}, 7 \%$ biochar amendment
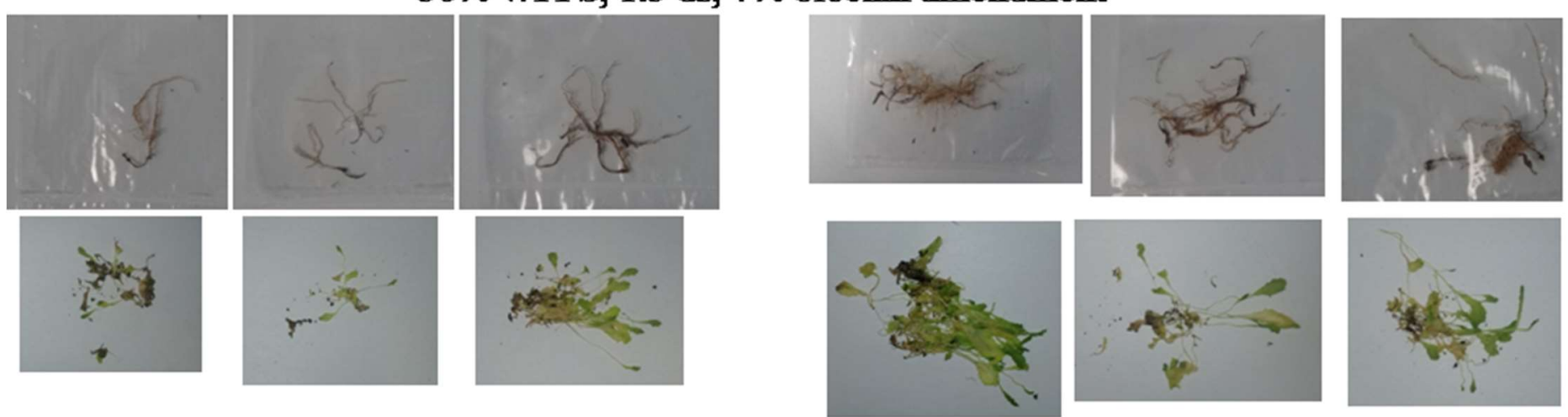

$30 \%$ WFPS, $1.3 \mathrm{ds}, 5 \%$ biochar amendment s
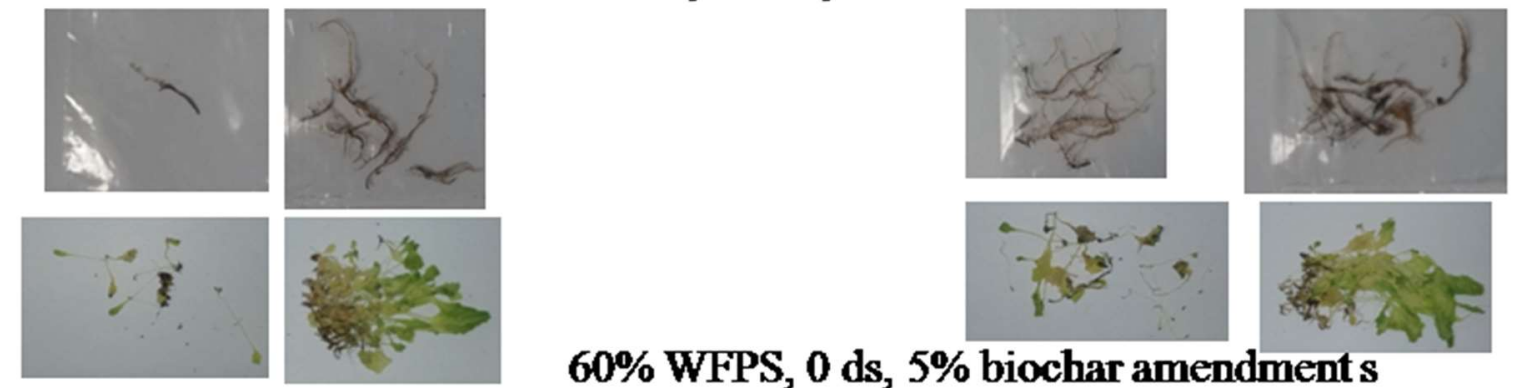

$60 \%$ WFPS, $0 \mathrm{ds}, 5 \%$ biochar amendment s
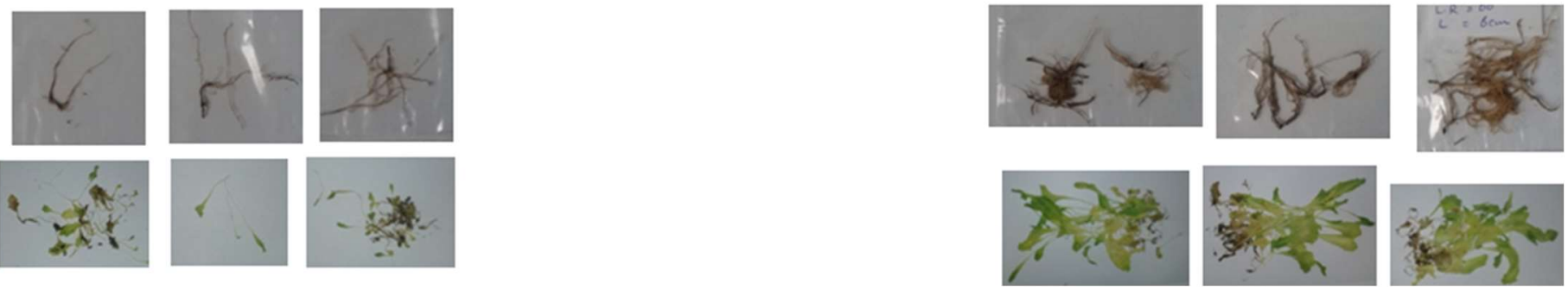

Figure 2: Pictures of aboveground plant biomass (leaves) and roots of lettuce plants grown under various treatments 
1. . Lehmann, J., Joseph, S. (2015). Biochar for environmental management: an introduction. Biochar for Environmental Management, Science, Technology and Implementation. eds. Lehmann, J., Joseph, S. Second edition, Routledge, https://doi.org/10.4324/9780203762264

2. Palansooriya, K. N., Ok, Y. S., Awad, Y. M., Lee, S. S., Sung, J. K., Koutsospyros, A., \& Moon, D. H. (2019). Impacts of biochar application on upland agriculture: A review. Journal of environmental management, 234, 52-64.

3. Gul, S., Whalen, J. K., Thomas, B. W., Sachdeva, V., \& Deng, H. (2015). Physico-chemical properties and microbial responses in biochar-amended soils: mechanisms and future directions. Agriculture, Ecosystems \& Environment, 206, 46-59.

4. Zhang, A., Li, X., Xing, J., \& Xu, G. (2020). Adsorption of potentially toxic elements in water by modified biochar: A review. Journal of Environmental Chemical Engineering, 8(4), 104196.

5. Gul, S., \& Whalen, J. K. (2016). Biochemical cycling of nitrogen and phosphorus in biochar-amended soils. Soil Biology and Biochemistry, 103, 1-15.

6. Haider, G., Joseph, S., Steffens, D., Müller, C., Taherymoosavi, S., Mitchell, D., \&Kammann, C. I. (2020). Mineral nitrogen captured in field-aged biochar is plantavailable. Scientific reports, 10(1), 1-12.

7. Wang, Y., Villamil, M. B., Davidson, P. C., \&Akdeniz, N. (2019). A quantitative understanding of the role of co-composted biochar in plant growth using metaanalysis. Science of the Total Environment, 685, 741-752.

8. Ghori, S. A., Gul, S., Tahir, S., Sohail, M., Batool, S., Shahwani, M. N., \&Bano, G. (2019). Wood-derived biochar influences nutrient use efficiency of heavy metals in spinach (Spinaciaoleracea) under groundwater and wastewater irrigation. Journal of Environmental Engineering and Landscape Management, 27(3), 144-152.

9. Manzoor, M., Gul, S., \& Khan, H. (2019). Influence of Biochars on Yield and Nitrogen and Phosphorus Use Efficiency of Pisumsativum under Groundwater and Wastewater Irrigation in Arid Climate. Communications in Soil Science and Plant Analysis, 50(13), 1563-1579.

10. Rizwan, M., Ali, S., Qayyum, M. F., Ibrahim, M., Zia-ur-Rehman, M., Abbas, T., \& Ok, Y. S. (2016). Mechanisms of biochar-mediated alleviation of toxicity of trace elements in plants: a critical review. Environmental Science and Pollution Research, 23(3), 22302248.

11. Samsuri, A. W., Fahmi, A. H., Jol, H., \&Daljit, S. (2020). Particle size and rate of biochar affected the phytoavailability of $\mathrm{Cd}$ and $\mathrm{Pb}$ by mustard plants grown in contaminated soils. International journal of phytoremediation, 22(6), 567-577.

12. Schmidt H-P, Kammann C, Hagemann N, Leifeld J, Bucheli TD, Monedero MAS, Cayuela ML (2021). Biochar in agriculture -A systematic review of 26 global meta-analyses. GCB Bioenergy 00:1-23. 
13. Kammann, C. I., Schmidt, H. P., Messerschmidt, N., Linsel, S., Steffens, D., Müller, C., \& Joseph, S. (2015). Plant growth improvement mediated by nitrate capture in co-composted biochar. Scientific reports, 5(1), 1-13.

14. El-Naggar, A., Lee, S. S., Rinklebe, J., Farooq, M., Song, H., Sarmah, A. K., \& Ok, Y. S. (2019). Biochar application to low fertility soils: A review of current status, and future prospects. Geoderma, 337, 536-554.

15. Zulfiqar, F., Thapa, G.B. (2017). Agricultural sustainability assessment at provincial level in Pakistan. Land Use Policy, 68, 492-502

16. Yang, A., Akhtar, S. S., Li, L., Fu, Q., Li, Q., Naeem, M. A. \& Jacobsen, S. E. (2020). Biochar mitigates combined effects of drought and salinity stress in quinoa. Agronomy, 10(6), 912.

17. Hafez, E. M., Omara, A. E. D., Alhumaydhi, F. A., \& El-Esawi, M. A. (2021). Minimizing hazard impacts of soil salinity and water stress on wheat plants by soil application of vermicompost and biochar. PhysiologiaPlantarum, 172(2), 587-602.

18. Ravindran, B., Nguyen, D. D., Chaudhary, D. K., Chang, S. W., Kim, J., Lee, S. R. \& Lee, J. (2019). Influence of biochar on physico-chemical and microbial community during swine manure composting process. Journal of environmental management, 232, 592-599

19. Hammer, E. C., Forstreuter, M., Rillig, M. C., \& Kohler, J. (2015). Biochar increases arbuscular mycorrhizal plant growth enhancement and ameliorates salinity stress. Applied soil ecology, 96, 114-121.

20. Gul, S., \& Whalen, J. K. (2013). Phenology, morphology, aboveground biomass and rootassociated soil respiration of Arabidopsis thaliana down-regulated cell wall mutants of MYB75, KNAT7, and CCR1. Pedobiologia, 56(2), 69-77.

21. Schimmelpfennig, S., Kammann, C., Moser, G., Grünhage, L., \& Müller, C. (2015). Changes in macro-and micronutrient contents of grasses and forbs following $\mathrm{M}$ iscanthus $\mathrm{x}$ giganteus feedstock, hydrochar and biochar application to temperate grassland. Grass and Forage Science, 70(4), 582-599.

22. Baligar, V. C., Fageria, N. K., \& He, Z. L. (2001). Nutrient use efficiency in plants. Communications in soil science and plant analysis, 32(7-8), 921-950.

23. Estefan, G., Sommer, R., \& Ryan, J. (2013). Methods of soil, plant, and water analysis: A manual for the West Asia and North Africa region. Beirut, Lebanon. Rolf Sommer, and John Ryan: International Center for Agricultural Research in the Dry Areas (ICARDA).

24. Sims, G. K., Ellsworth, T. R., \& Mulvaney, R. L. (1995). Microscale determination of inorganic nitrogen in water and soil extracts. Communications in soil science and plant analysis, 26(1-2), 303-316.

25. D'Angelo, E., Crutchfield, J., \& Vandiviere, M. (2001). Rapid, sensitive, microscale determination of phosphate in water and soil. Journal of environmental quality, 30(6), 2206-2209.

26. Zainul, A., Koyro, H. W., Huchzermeyer, B., Gul, B., \& Khan, M. A. (2017). Impact of a Biochar or a Compost-Biochar Mixture on Water relation, Nutrient uptake and Photosynthesis of Phragmiteskarka. Pedosphere, 160. 
27. Qayyum, M. F., Liaquat, F., Rehman, R. A., Gul, M., ulHye, M. Z., Rizwan, M., \&urRehaman, M. Z. (2017). Effects of co-composting of farm manure and biochar on plant growth and carbon mineralization in an alkaline soil. Environmental Science and Pollution Research, 24(33), 26060-26068.

28. Das, S. K., Ghosh, G. K., Avasthe, R., Kundu, M. C., Choudhury, B. U., Baruah, K., \& Lama, A. (2021). Innovative biochar and organic manure co-composting technology for yield maximization in maize-black gram cropping system. Biomass Conversion and Biorefinery, 1-13.

29. Zeeshan, M., Ahmad, W., Hussain, F., Ahmad, W., Numan, M., Shah, M., Ahmad, I. (2020). Phytostabalization of the heavy metals in the soil with biochar applications, the impact on chlorophyll, carotene, soil fertility and tomato crop yield. Journal of Cleaner Producetion, 255, 120318.

30. Egamberdieva, D., Ma, H., Alaylar, B., Zoghi, Z., Kistaubayeva, A., Wirth, S., \&Bellingrath-Kimura, S. D. (2021). Biochar Amendments Improve Licorice (Glycyrrhiza uralensis Fisch.) Growth and Nutrient Uptake under Salt Stress. Plants, 10(10), 2135.

31. Agegnehu, G., Nelson, P. N., Bird, N. I. (2016). The effects of biochar, compost and their mixture and nitrogen fertilizer on yield and nitrogen use efficiency of barley grown on a Nitisol in the highlands of Ethiopia. Science of the Total Environment, 569-570, 869-879.

32. Luo, X., Liu, G., Xia, Y., Chen, L., Jiang, Z., Zheng, H., Wang, Z. (2017). Use of biocharcompost to improve properties and productivity of the degraded coastal soil in the Yellow River Delta, China. Journal of Soils and Sediments, 17, 780-789.

33. Kaudal, B. B., Weatherley, A. J. (2018). Agronomic effectiveness of urban biochar aged through co-composting with food waste. Waste Management, 77, 87-97.

34. Mishra, A., Kuchhal, P., Nasim, M., Sharma, U.C. 2021. Extraction and Characterization of Sesbania cannabina (Retz.) Pers. (Dhaincha) Seed Oil for Potential Engineering Applications. Journal of Oleo Science 70(6):777-785

35. Joseph, S., Cowie, A.L., Zwieten, L.V., Bolan, N., Budai, A., Buss, W., Cayuela, M.L., Graber, E.R., Ippolito, J.A., Kuzyakov, Y., Luo, Y., Ok, Y.S., Palansooriya, K.N., Shepherd, J., Stephens, S., Weng, Z (H)., Lehmann, J. (2021). How biochar works, and when it doesn't: A review of mechanisms controlling soil and plant responses to biochar. GCB Bioenergy, 00, 1-34.

36. Hagemann N, Joseph S, Schmidt H-P, Kammann CI, Harter J, Borch T, Young RB, Varga K, Taherymoosavi S, Elliott KW, McKenna A, Albu M, Mayrhofer C, Obst M, Conte P, Dieguez-Alonso A, Orsetti S, Subdiaga E, Behrens S and Kappler A (2017). Organic coating on biochar explains its nutrientretention and stimulation of soil fertility. Nature Communications 8, 1089.

37. Antonangelo, J., Sun, X., Zhang, H. (2021). The roles of co-composted biochar (COMBI) in improving soil quality, crop productivity, and toxic metal amelioration. Journal of Environmental Management, 277, 111443.

38. Deng, H., Ejack, L., Gul, S., Prasher, S. O., Whalen, J. K. 2021. Slow pyrolysis pine woodderived biochar reduces nitrous oxide production from surface but not subsurface soil. Canadian Journal of Soil Science 00: 1-8 (0000) dx.doi.org/10.1139/cjss-2021-0017. 
39. Ding, Z., Mairashi, M. A., Ghoneim, A. M., Ali, E. F., Eissa, M. A., Shal, R. E. (2022). Irrigation and biochar effects on pearl millet and kinetics of ammonia volatilization from saline sandy soils. Journal of Soil Science and Plant Nutrition https://doi.org/10.1007/s42729-021-00753-0.

40. Glaser, B., \& Lehr, V. I. (2019). Biochar effects on phosphorus availability in agricultural soils: A meta-analysis. Scientific reports, 9(1), 1-9.

41. Hannet, G., Singh, K., Fidelis, C., Farrar, M. B., Muqaddas, B., \& Bai, S. H. (2021). Effects of biochar, compost, and biochar-compost on soil total nitrogen and available phosphorus concentrations in a corn field in Papua New Guinea. Environmental Science and Pollution Research, 28(21), 27411-27419.

Khan, I., Fahad, S., Wu, L., Zhou, W., Xu, P., Sun, Z., Salam, A., Imran, M., Jiang, M., Kuzyakov, Y., Hu, R. (2019). Labile organic matter intensifies phosphorous mobilization in paddy soils by microbial iron (III 